\section{THE ASS WHO SPOKE}

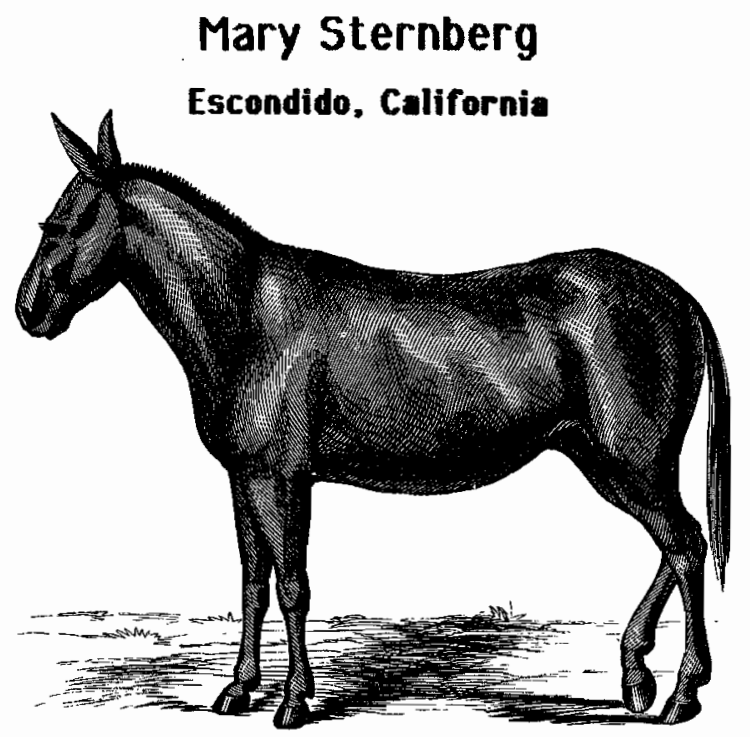

Some people have an aversion to stories in which talking animals appear. They say pompously, "I want no anthropomorphizing. We all know that animals can't talk."

But do we? Not if we consult the Bible. In the Old Testament (Numbers 22), there was a fellow named Balaam who had a most remarkable donkey, or ass, as she was called, but somehow it sounds funny to say, "Balaam had a most remarkable ass." Anyway, this ass not only had the power of speech, she also was able to see the invisible.

As the story goes, Balaam had apparently misunderstood God's advice not to join Moab and fight against the Israelites. As his ass was carrying him to meet Moab, all of a sudden she stopped stark still because she saw an angel standing in their path with sword drawn and not looking one bit friendly.

Balaam, wanting to be on his way, gave the ass a sharp blow with his staff. The ass refused to go forward and turned into a field instead, which made Balaam so angry that he struck her even harder. Seeing a vineyard with a wall on either side, the ass leaned in, pushing Balaam's foot against the wall in the hope that this would give him a hint that something was wrong. Balaam never got the point but just kept hitting the ass until she fell down.

God, then, opened the mouth of the ass who said, "What have I done to thee? Why strikest

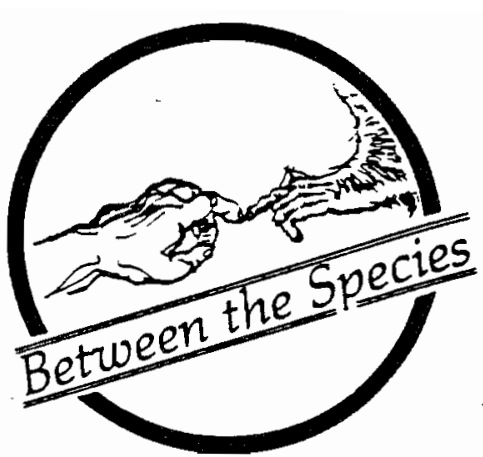

thou me, lo, now this third time?"

Balaam didn't even notice this amazing speech ability of the ass. He just answered that if he had a sword, he'd kill her.

Realizing how dense and insensitive Balaam was, God saw that it was time to open Balaam's eyes and show him what was disturbing the ass.

When Balaam saw the angel, he must have been more than a bit embarrassed because he "fell flat on his face." The angel told him that his ways were "perverse and contrary" and that if the ass hadn't had such good sense and turned aside three times, surely Balaam would have been a dead turkey.

After such a fantastic experience, you'd think that Balaam would feel so grateful to that ass that he'd at least give her an extra carrot or two. The ungrateful bully didn't give her so much as a word of appreciation, let alone a carrot. You can be sure he had never seen a talking ass before, but he acted as though it were an everyday occurrence. He just hopped on her back again and followed the directive of the angel, which was to proceed but always to keep to God's word.

That ass certainly got her lesson in the uncharitableness of human beings. She'd probably think twice before trying to help one of the blighters again.

Balaam stood firm in God's will not to go against the Israelites no matter how much the Moabites kept after him to do so. This shows that

(C) Mary Sternberg, 1988

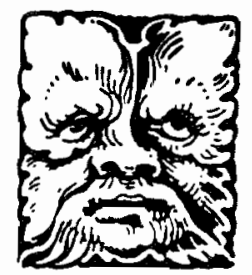


even some fairly rotten people have a good side to them. Finally, Balaam went on back to Pethor, or wherever he lived, and I guess he took his remarkable ass with him.

I always wonder what happened to that ass. Who knows, maybe she was the several times great-grandmother of the donkey who carried Jesus.

What would happen if God were to open the mouths of certain animals today? He wouldn't have to open the mouths of very many, just those of a few animals in key positions would be enough to produce quite an effect. News of earthquakes and terrorist bomb explosions would all take a back page to the news of what the animals said on the day God opened their mouths.

Suppose, for example, that you took your little girl to the zoo one day, and as you stood gaping in front of the gorilla exhibit, your child hollered to the gorilla, "Mrs. Gorilla, would you eat me?"

As people around you began to titter, suddenly the gorilla opened her mouth and said, "I don't eat my brothers; in fact, I eat no flesh at all. I'm a strict vegetarian."

God gave the gorilla this power, much as he had Balaam's ass, just because He was so tired of the human animal's consistently ignorant attitudes towards God's other creatures.

Can you imagine the ruckus this would cause at the zoo? In five minutes the zoo director, the veterinarian and half the zoo staff would be in there taking the gorilla's temperature and looking down her throat. Everything would stop for the day at the zoo. The media would soon get word, and with TV cameras on her, reporters interviewing her, and everyone screaming and gawking, that would be one sorry gorilla - sorry, that is, that she had ever opened her mouth. Now she was not only a prisoner, she was an international curiosity as well.

Ultimately, they'd send her to the experimental laboratories where they'd question, probe, operate and finally vivisect her to death in their attempts to find out how she was able to talk. Since her speech had been a gift from God, of course they'd never learn a thing.

After God saw what happened to that poor gorilla just because He let her say a sentence or two, He had some second thoughts about letting animals talk. It seemed to give people a big thrill, but it surely didn't do much for the animals.

Before long, however, after God had been watching for so many years the thousands upon thousands of pigs enter Harmours Killing Factory to get slaughtered and made into something people euphemistically called "ham" and "bacon," God changed His mind.

One day, as a long line of pigs was being shoved up the ramp with sharp electric prods at Harmours, one pig stopped dead in his tracks and said, "You can stab me to death right here because I can sense the torture I face inside, so I won't go another step."

The man who had been poking the pig dropped his prod and almost fell off the ramp.

This one pig ruined the whole day at Harmours. They took him and shut him up in a cage until the proper authorities could get there. The other pigs in line for execution began to squeal and run so ferociously that no one could handle them. Finally, they broke down the doors and dispersed themselves over the countryside.

The pig executioners were all so dumb-struck that they repaired to the local pubs for solace. It was a sad day for poor Mr. Harmour. He lost almost as much money as he had during the last strike.

But what about the talking pig? For a while he got the royal treatment. Miss Piggy herself never had it so good. The vivisectors weren't going to make the mistake of destroying this valuable animal until they found out what made him tick and talk.

They bribed the pig to tell them his secret. They went so far as to tell him that he would be allowed to live a normal pig's life in a clean sty with plenty of cool mud to wallow in, fresh warm straw to sleep on, and good fresh food served in a clean trough. He'd have a green pasture to exercise in and fellow pigs for company.

The pig was convinced that he had died and gone to Heaven, but no more words issued from his mouth, so eventually the poor pig received the same treatment the gorilla had received. He got probed, stabbed, sliced and vivisected until there wasn't a squeal left in him.

There was only one thing that was different. After TV, magazine and newspaper coverage of the pig that talked, most people weren't enjoying their ham sandwiches much anymore. The sale of 
ham dropped appreciably.

No more talking animals appeared for many months until one day in a so-called "burns institute" down in Texas, a sheep who was about to be scorched over three-quarters of her body with a blow torch, opened her mouth. This sheep was only one in hundreds who had for many years been getting the burn treatment. First they seared the sheep, then blew smoke into their lungs and finally filled their lungs with water to see how long it would take them to drown.

This sheep, No. 580, as she was labelled, asked a good question. She said, "Since you already know about burns from what happened to human beings and animals in real fires, why do you continue to torture us? What have sheep ever done to you?"

The sheep torturers (called researchers and technicians) didn't answer the sheep any more than Balaam had answered his ass. They were too knocked off their pins to say anything. The guy holding the blow torch turned it off and stood there gaping. The others unstrapped the sheep, stood her up, and tried to get her to speak again. She just looked at them with her cold blue eyes but said nothing more.

Just as at Harmours, this shot the whole day for those researchers. They were so upset that they had to take to their beds with double shots of Wild Turkey.

As for the sheep, she was put on exhibition for awhile, but since she wouldn't talk any more, she was no money-maker, so she met a similar fate to the gorilla and the pig.

When God saw the sad end of His last talking animal, He decided that these twentieth century people were not only as stiff-necked as the ancient Israelites, but they seemed to be a lot stupider and more callous, too. He found it discouraging that after all these thousands of years people seemed, if anything, to have retrogressed in their understanding of the non-human creatures. Even the Israelites had been kind enough not to muzzle the oxen that trod their grain.

God wondered, "Should $\mathrm{He}$ stand back as $\mathrm{He}$ had previously done and let these people learn the hard way through their own bitter experience, or should He step in, as He so often had done with the Israelites, and give them a boost in the right direction?"

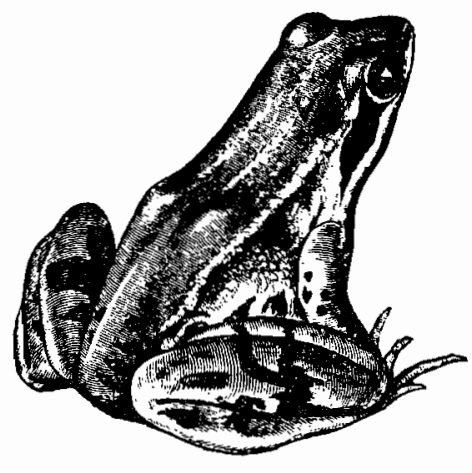

He figured that if $\mathrm{He}$ didn't step in soon there would be no more non-human creatures on earth, or maybe no human ones either. Considering the rate at which human beings were destroying every natural aspect of their world, the planet earth simply couldn't tolerate much more abuse.

Just like the Israelites, whenever God turned His back for a second, twentieth century people proceeded to cut every manner of outrageous caper. They were incurable Hedonists - money, possessions, and fun were their objectives with the automobile as their Golden Calf.

You remember in the bible when God had seen the Israelites worshipping the Golden Calf and engaging in an exorbitant orgy, $\mathrm{He}$ was so discouraged that $\mathrm{He}$ temporarily washed His hands of them and turned them over to Moses for punishment.

Moses, who could never be accused of indecisiveness, walked right into the midst of the orgy, grabbed the Golden Calf, burnt it in the fire, ground it to powder and put it into water which he made the Israelites drink. Maybe you think that didn't put some crimps in the Israelites' frivolity. 
God wished He had Moses to turn to now, but St. Francis of Assisi, Mahatma Gandhi and Albert Schweitzer were all dead, and anyway very few people had listened to them when they were alive, so what was $\mathrm{He}$ to do?

Then God remembered what He had done with Balaam. He had opened Balaam's eyes so that Balaam, whether he wanted to or not, had to see what was going on. "Why not open some more unwilling eyes?" He thought.

One beautiful morning - in actual fact, it was October 4, the birthday of St. Francis of Assisi a strange thing happened.

A group of people whom you would least suspect of doing so, were talking about animals. For these particular people, it had always been as though animals didn't exist. If anyone mentioned animals to them, they'd say things such as, "They have no souls," or "They aren't rational," or "They were put here for our use." Then the subject would be dropped as of no consequence.

Now, all of a sudden, in every town and city in the country, these same people were standing in front of their congregations on the same morning, and they were all giving the same sermon. Such a thing had never been conceived of before - that there could be unity about anything among these many diverse sects.

But here was true unity at last. They all said nearly the same thing. It was clear and to the point, and it went something like this:

My dear Brothers and Sisters, a most astounding thing has happened to me. I have no explanation for it except that it had to be a Divine Gift. My eyes have been opened, and I have seen what human beings are doing to non-human creatures behind closed doors. I have seen the experimental laboratories. I have seen the slaughterhouses. I have seen how the animals we eat are raised. I have seen animals caught in leg-hold traps. I have been behind the scenes at zoos, circuses and rodeos. I have truly seen it all, and I'm going to tell you about it today.

The sermon was a long one, but according to later reports, no one left or went to sleep. When the church and temple doors opened and people departed for home, not a sound was to be heard. The people were stunned into silence. Some of the more sensitive ones couldn't speak for days.

As God watched, He said, "Stiffnecked as they are, this may finally have an effect."
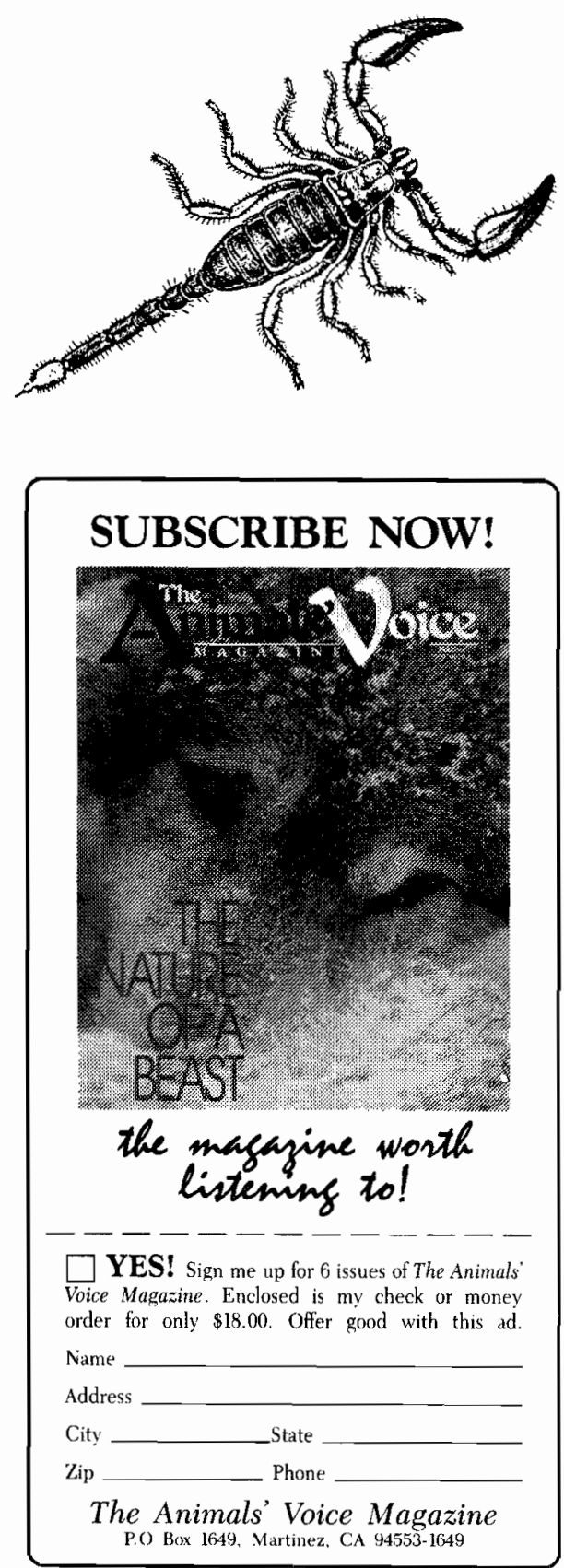